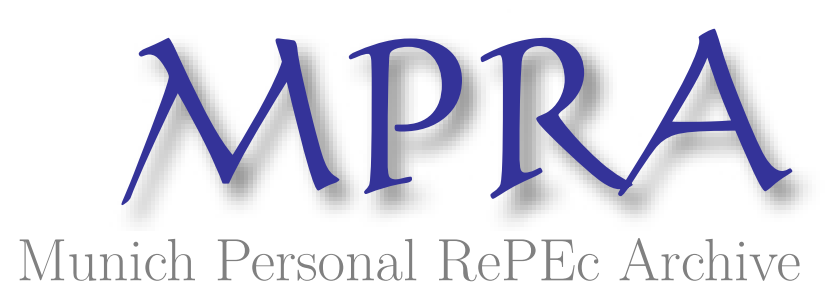

\title{
Dispelling Some Myths About Offshoring
}

Harrison, Ann E. and McMillan, Margaret S.

University of California, Berkeley, Tufts University

2006

Online at https://mpra.ub.uni-muenchen.de/15615/

MPRA Paper No. 15615, posted 10 Jun 2009 06:05 UTC 


\section{Dispelling Some Myths About Offshoring}

by Ann E. Harrison and Margaret S. McMillan

\section{Executive Overview}

Critics of globalization claim that firms are being driven to shift employment abroad by the prospects of cheaper labor. Yet the evidence for this, beyond anecdotes, is slim. In this article, we review evidence on whether firms that do business in foreign countries are substituting foreign for domestic labor. We review the results of previous studies and present new firm-level evidence showing that, in fact, increases in employment in low-income countries do hurt employment at home. The premise that foreign expansion of U.S. multinationals encourages employment at home is a myth, but the domestic employment costs of offshoring are probably fairly small in magnitude.

C ritics of globalization claim that U.S. firms are shutting down factories at home and shifting employment abroad to countries with cheaper labor and lower labor standards. Yet the evidence for this, beyond anecdotes, is slim. Are U.S. employers really expanding in low cost locations and contracting employment at home? In a now-infamous press conference for the Economic Report of the President (2004), Gregory Mankiw pointed out that U.S. outsourcing is good for the U.S. economy. More recently, Mankiw and his coauthor, Phillip Swagel, have further argued that "increased employment in the overseas affiliates of U.S. multinationals is associated with more employment in the U.S. parent rather than less."

Whether doing business abroad creates domestic jobs continues to be a contentious topic in the U.S. Congress. The most recent controversy centers on a 2004 Department of Commerce (DOC) report on workforce globalization in high-tech industries, which the Administration refused to

For financial assistance the authors gratefully acknowledge the $\mathrm{Na}$ tional Science Foundation. McMillan acknowledges the Radcliffe Institute for Advanced Study for both financial support and time to devote to this project. The statistical analysis of firm-level data on U.S. multinational companies was conducted at the International Investment Division, Bureau of Economic Analysis, U.S. Department of Commerce under arrangements that maintain legal confidentiality requirements. The views expressed in this paper are those of the authors and do not reflect official positions of the U.S. Department of Commerce. Research assistance from Joan Hamory, Clair Null and Andrew Waxman is gratefully acknowledged. release for over two years. After repeated Congressional inquiries, the government issued a 12-page "summary" in 2005 which clearly glosses over the job costs of outsourcing and the cost-cutting motivation emphasized in the original report. The fact that some administration officials may have felt it necessary initially to cover up findings from the 2004 report suggests that the impact of expansion abroad on U.S. jobs remains an important political issue.

It seems intuitively obvious that the increased internationalization of U.S. business could be accompanied by downsizing at home. This is only natural as the U.S. loses its comparative advantage in producing some types of goods (for example, apparel) and shifts to the production of other goods (aircraft, high-tech). According to standard trade theory, losses to some groups from shifting comparative advantage are outweighed by the overall gains which accrue to the economy in the form of lower priced goods for consumers, higher profits for enterprises, and better jobs for workers in industries where the U.S. has a comparative advantage.

Why should offshore activities-either through outsourcing or outward foreign investment (the expansion of U.S. affiliates abroad) be perceived any differently than international trade in goods? Just as international trade benefits

* Ann E. Harrison (harrison@are.berkeley.edu) is a Professor of Agricultural and Resource Economics at University of California, Berkeley. Margaret S. McMillan (mmcmilla@tufts.edu) is an Associate Professor of Economics at Tufts University. 
the economy as a whole, but creates both winners and losers in the domestic economy, we would expect some winners and losers from offshoring as well. The winners are likely to be the owners of firms who are able to increase profits by finding lower labor or investment costs abroad, as well as the workers whose jobs are made easier by having access to a global labor force. A concrete example of this is Oracle, which employs thousands of workers in southern India to do tasks that could not be done easily or cheaply in California. The losers are those who must now compete with workers in foreign locations, whether these are steel workers in Brazil or computer programmers in Bangalore. Estimating whether a group of U.S. workers are helped or hurt by offshoring is even more difficult if the firm could not have survived without spinning off some of its activities abroad. What is clear, however, is that there will be losers within the U.S. labor force, just as there are both winners and losers from international trade.

Yet several prominent economists have argued that firms doing business overseas are expanding the manufacturing labor force both in the United States and abroad. Such an argument is difficult to reconcile with the fact that U.S. multinational firms shed more than 3 million manufacturing jobs (net) in the U.S. between 1977 and 1999, while expanding employment in low-income countries ${ }^{1}$. Indeed, firms like Mattel and Levi Strauss that once employed a significant number of workers in the U.S. no longer manufacture in the United States. Where does this evidence for the job-creating effects of offshore outsourcing come from?

We begin the first half of this essay by reviewing the existing evidence on the domestic employment effects of relocating economic activity abroad, drawing primarily on studies done on the United States. To date, almost all the academic research in this field has focused on manufacturing, not services. This is primarily because the available data on services activity overseas represent such a tiny fraction of services activity in the U.S. that it is difficult to know what to make of

\footnotetext{
${ }^{1}$ Our numbers differ from official BEA statistics because we do not use data estimated by the BEA.
}

these data. For this reason, most of our discussion focuses on trends in manufacturing.

In the second half of this paper, we present our own evidence on the impact of offshoring on U.S. jobs and U.S. investment, drawing on firm-level data collected by the Bureau of Economic Analysis (BEA) in Washington, D.C. As pointed out by Mankiw and Swagel, "The BEA data are today essentially the only solid numbers on the activities of U.S. multinationals." The firms surveyed account for approximately 60 percent of U.S. sales and employment in manufacturing, 70 percent of exports, and 80 percent of private $R \& D$ in manufacturing, a sizeable share of the U.S. economy. ${ }^{2}$ The dataset also includes information on other international activities of U.S. enterprises, such as trade, investment, and research and development activities of the parents and affiliates. Our own results indicate that many factors have contributed to the net decline in U.S. manufacturing employment of multinational firms, including physical investment in affiliates, trade, and technological change.

Our research points out an important omission in almost all of the previous work in this area. The relationship between employment in the U.S. and abroad within multinational firms depends on whether the U.S. subsidiary (called an "affiliate") is located in a high-or low-income country. Aggregating across all locations, employment expansions and contractions in U.S. multinational parents and their affiliates move, on average, in the same direction. However, these averages mask significant heterogeneity across different kinds of enterprises. In developed countries, the positive relationship between employment at home and abroad is driven by contraction in both locations: the overall contraction in U.S. manufacturing employment has been accompanied by an overall contraction in affiliate employment. For parents that hire workers in developed countries-roughly half the sample-the story is different. For these firms, the contraction in U.S. manufacturing employment has been accompanied by an increase in affiliate employment.

This evidence highlights the importance of dif-

\footnotetext{
${ }^{2}$ This is for the period 1982-1999.
} 
ferentiating between jobs in low-income countries and jobs in developed (or industrialized) countries. It also helps to reconcile academic arguments for complementarity with anecdotal evidence in the popular press of factory closings and falling manufacturing employment. To summarize, our research suggests that the decline in U.S. manufacturing employment is driven by a number of factors, including (but not limited to) relocation of activities to low-income countries. Before reporting these new results, however, we begin by defining some terms and reviewing the previous literature.

\section{Distinguishing befween Offshoring and Outsourcing}

0 utsourcing means a firm purchases inputs or services from another firm. A U.S. firm could outsource either goods (i.e., car parts) or services (i.e., call centers). Outsourcing can be done at home or abroad. For example, in the electronics industry, several of the large contract manufacturers, like Solectron, are U.S.-based multinationals. When IBM outsources to Solectron, it is outsourcing its business to another U.S. firm. By contrast, if IBM outsources to a Chinese contract manufacturer, we call this offshore outsourcing or offshoring. This latter type of outsourcing is very difficult to measure because it would require detailed firm level data on both U.S. companies and foreign companies.

Offshoring refers to a broad range of tasks executed by a firm in another country that could include setting up a foreign subsidiary or outsourcing offshore through an arm's length agreement with another firm. ${ }^{3}$ While offshore outsourcing was primarily restricted to manufacturing activity in earlier decades, in recent years firms have begun to outsource services, such as back office processing or call center activity, to foreign parties. In the United States, firms that set up foreign subsidiaries are called U.S. based multinationals.

\footnotetext{
${ }^{3}$ There is not complete consensus on these definitions, however. Bhagwati, Panagariya, and Srinivasan (2004) define outsourcing as the offshore trade in arm's-length services, while others such as Trefler (2005) adopt a broader perspective and refer to outsourcing in either goods or services.
}

If a U.S. firm owns at least 10 percent of a company abroad, this is referred to as direct foreign investment. The company that has made the direct investment is called the "parent" and the foreign business enterprise is called the "affiliate." U.S. companies frequently purchase final goods from abroad either from third parties or from their own affiliates through intra-firm trade or both. They also sell and invest in foreign markets. From an economist's viewpoint, these different aspects of doing business abroad are all equally important and likely to affect U.S. labor. ${ }^{4}$

\section{Assessing the Previous Literature}

- anson, Mataloni, and Slaughter (2003) show that employment of low-skilled workers in foreign affiliates of U.S. corporations reduces employment in the U.S. The size of the effect is significant, suggesting that a 10 percent fall in affiliate wages would reduce U.S. labor demand by 3 percent. To use these results to identify the actual impact of foreign employment on U.S. wages, we need a number for the actual change in foreign affiliate wages. Our own research shows that low-income affiliate wages fell by 50 percent between 1982 and 1999. If we combine this information on wage trends with the estimates in Hanson et al., this implies a fall in demand for labor by U.S. multinationals of 15 percentage points. As pointed out by Hanson, Mataloni, and Slaughter, "This finding is consistent with the idea that expansion abroad exposes workers in U.S. parents to competition from foreign labor." 5 Yet Hanson et al. also find that higher sales abroad of U.S. parents is associated with expanded employment at home. In other words, when U.S.

\footnotetext{
${ }^{4}$ All of the work that we review studies the form of offshoring that involves setting up a foreign affiliate. This is partially a limitation of the data. However, in our own work, we show that previous work has overlooked important aspects of offshoring, such as investment abroad, that are likely to impact domestic employment. We also investigate the impact of imports from third parties on parent employment. Since it is unclear whether these imports are intermediate inputs or final goods, we cannot say for sure whether these imports represent offshore outsourcing.

${ }^{5}$ See page 19 in their paper. Oddly, and this is perhaps the reason why Mankiw and Swagel were confused, Hanson et al. in their abstract conclude that "we do not find strong evidence that foreign and parent labor are substitutes." Perhaps, since one of the authors now sits on the Council of Economic Advisors, this disconnect between their actual findings and their abstract reflects wishful thinking on their part.
} 
foreign affiliates increase sales in other countries, U.S. labor benefits from this activity. Mankiw and Swagel (2006) emphasize this result, pointing out that "success overseas leads to job gains in the United States."

We believe that such a conclusion is too optimistic. Why? When a U.S. firm increases sales abroad through foreign direct investment in another country, this is typically accompanied by investments in building capacity abroad, which means less investment at home and consequently less job creation. In our own work, we confirm that foreign sales increase U.S. jobs, but we also show that physical investment in affiliates and employment in affiliates, as well as imports from affiliates, generate employment losses at home. The net impact of these offsetting forces has been to reduce manufacturing employment.

These results point to one way in which the effects of offshoring differ from the impact of international trade on the domestic economy. In the case of international trade, domestic enterprises respond to international competition by shifting to the production of goods in which the U.S. economy has a comparative advantage. This means that investment by firms remains at home as companies invest less in apparel factories and more in high technology development. With offshoring however, our research confirms that expansion in affiliates is accompanied by a shifting of new investment to foreign locations. This means that international expansion will have long-term effects as firms choose to invest and develop new products outside the United States.

The only research which unambiguously finds a positive relationship between hiring at home and abroad by U.S. multinationals is the recent working paper by Desai, Foley, and Hines (2005). Desai et al., using the same BEA dataset as Hanson et al., find that an additional $\$ 10$ dollars of foreign capital investment is associated with $\$ 15$ additional domestic investment, and increasing foreign employment is associated with increasing employment at home. Mankiw and Swagel conclude from this that "foreign activity does not crowd out domestic activity; the reverse is true" (p. 30).

We would like to emphasize the broad similar- ity between our findings and those of Hanson et al., both of which are at odds with the claims of Mankiw and Swagel (2006). Hanson et al. find that low-skilled employment abroad substitutes for U.S. employment, while high-skilled employment abroad is complementary to U.S. employment. As we show in our own research, measuring the impact of foreign affiliate employment in high-and low-income countries on U.S. parent employment leads to very different results. Consistent with Hanson et al., we find that employment in low-income affiliates does indeed crowd out U.S. employment. Employment in highincome affiliates of U.S. companies abroad is positively correlated with employment in low-income affiliates because employment has contracted in both high-income affiliates and the United States. To summarize, employment in low-income affiliates crowds out U.S. employment, while employment in high-income affiliates moves in the same direction as employment in the U.S.

In addition, our results show that when U.S. multinationals increase capital investment abroad, this reduces employment at home. This is true whether or not that capital is invested in high- or low-income affiliates. Why do these results differ from Desai et al., who are using the same data? This is because they only perform pair-wise correlations: U.S. versus foreign employment, physical investment abroad versus at home. They do not examine the impact of capital investment abroad on employment at home, in a multivariate regression.

Other related work includes Brainard and Riker (1997, 2001), Muendler and Becker (2006), and Bernard, Jensen, and Schott (2005). Both Brainard and Riker (1997) and Brainard and Riker (2001) use the same BEA manufacturing data, for 1983 to 1992, which makes it somewhat less current than other studies. Their 1997 working paper focuses only on employment in the foreign operations of U.S. companies and shows that labor demand across high-and low-income locations is, in fact, complementary. This means that employment in high- and low-income offshore locations is positively related: when a U.S. company's operations expand in Germany, they simultaneously 
expand in countries such as Mexico and China. However, affiliate employment decisions across different locations within the same region are substitutes. This suggests that the employment of a U.S. corporation in China would be a substitute for employment in Indonesia as the latter are in the same region (or Mexico and Honduras), but employment of a U.S. firm in China would be complementary with affiliate employment in Canada as these two are in different regions.

Brainard and Riker (2001) use a translog cost function approach to derive the implied substitutability between labor employed by the U.S. parent and its affiliates. Unlike their earlier paper, this study includes employment decisions within the U.S. as well. They find that foreign affiliate employment abroad is a substitute for employment in the U.S., but the magnitudes are small. Foreign employees in both high- and lowincome affiliate locations substitute for U.S. employment: for low-income affiliates, a 10 percentage point decline in wages would be associated with a .15 percent fall in U.S. employment, while a 10 percentage point decline in high-income affiliate wages would be associated with a 1.1 percent fall in U.S. employment. The fact that Brainard and Riker (2001) reach different conclusions than Brainard and Riker (1997) can be in part attributed to a different methodology and also to the use of different samples from the BEA data. While Brainard and Riker (1997) restrict their work to non-U.S. locations, Brainard and Riker (2001) focus on U.S. employment outcomes. It is this latter research focusing on the U.S. that finds evidence that "labor abroad substitutes for parent labor" (Brainard and Riker (2001), p. 13).

Recent work by Muendler and Becker suggests that the European experience is similar. Two papers, by Muendler et al. (2005) and Muendler and Becker (2006) have examined the impact of offshore outsourcing on domestic employment in Sweden and Germany. Both studies find that foreign affiliate employment is a substitute for employment in a company's home country, but again the magnitudes are small. The results for Germany and Sweden are remarkably similar to those re- ported by Brainard and Riker (2001), suggesting a pattern of substitution between employment at home and abroad.

To summarize, the degree to which foreign employment affects domestic labor outcomes will depend critically on where the offshoring activity is located. The expansion of operations and jobs in high-income countries is likely to have very different effects on a company's employment in the U.S. than is an expansion of operations and jobs in low-income countries on U.S. labor market outcomes. We will see later in this essay that the reason is because expansion into low-income countries is motivated by cost-cutting, while expansion into high-income countries is driven by the need to break into foreign markets. This hypothesis regarding U.S. multinational activity is consistent with evidence on the employment effects of import competition presented by Bernard, Jensen, and Schott (2005). Bernard et al. examine the impact of U.S. imports on both the survival and employment of U.S. manufacturing firms. They find that imports only harm U.S. manufacturing employment when those imports are from low wage countries.

\section{An Economic Cover-up?}

B eyond the research findings, we need to put this issue in a political context. Indeed, the question of whether multinational expansion abroad creates jobs at home continues to be a contentious topic in the U.S. Congress. The most recent controversy centers on a 2004 Department of Commerce (DOC) report on workforce globalization in high-tech industries, which was not released despite ongoing pressure from Congress. After repeated Congressional inquiries, the government issued a 12-page "summary" report in September 2005 that the Commerce Department staff claimed did not accurately reflect the original report. Indeed the summary report claims that for every job created abroad, multinationals create nearly two jobs at home (p. 2). This claim is not in the original DOC 2004 report, but is based on 
research by Matthew Slaughter (2003), now on the Council of Economic Advisors. ${ }^{6}$

The original 2004 DOC report, which is now publicly available, suggests that both employment gains and losses are possible from offshore outsourcing. ${ }^{7}$ For example, in semiconductors, one of the three high-tech industries scrutinized in the study, the authors report that "the number of engineers employed offshore by U.S. semiconductor companies rose by more than 10,000 between 2000 and 2003, while engineers employed in the United States dropped by 4,000 during the same period." In contrast, the so-called summary report claims that the U.S. semiconductor industry "remains the leader in world market share," and points out that highly skilled workers will remain mostly in the United States (p.7). And while the full report emphasizes that a major reason for relocation is labor cost reduction, the summary report glosses over this economic relationship, merely noting that the U.S. remains a market leader in high tech and that international activity is likely to promote employment at home.

Although the 2004 report would not be particularly controversial from a researcher's point of view, it does point out that there may be both employment gains as well as losses from offshore outsourcing, a marked difference from the conclusion drawn in the 2005 summary report. The fact that some administration officials may have felt it necessary to present a more rosy picture and withhold release of the original study suggests how protective the administration has become over such a sensitive issue.

How were the authors of the summary report able to put such a rosy spin on the facts? The summary report cites work by CEA member Matthew Slaughter (2003) to argue that U.S. multinationals create jobs at home when they expand abroad. He points out that there are many reasons why a U.S. multinational might set up affiliates abroad apart from seeking low cost labor, such as the desire to access foreign markets. Yet his con-

\footnotetext{
${ }^{6}$ See footnote 4, page 2, in the "Six Month Assessment of Workforce Globalization in Certain-Knowledge-Based Industries," Technology Administration, Department of Commerce, September 2005.

${ }^{7}$ The original report is available at http://sciencedems.house.gov/investigations/investigations_detail.
}

tention that "U.S. multinationals have been a major force behind job creation, not job destruction" is in direct opposition to work he conducted with Hanson and Mataloni (2003) showing that employment of low-skilled workers in foreign affiliates reduces employment in the U.S.

The reason the two studies come to different conclusions is because Slaughter (2003) reports total employment of U.S. multinationals across all sectors of the economy, while Hanson, Mataloni, and Slaughter (2003) are restricted to manufacturing. Within the manufacturing sector, enterprises cut their U.S. labor force and increased employment in developing countries. As manufacturing growth in the U.S. slowed, these companies expanded into services and wholesale trade, increasing the number of jobs there. Since there was almost no affiliate activity in the 1990s in services or wholesale trade abroad, in the aggregate it is possible to show that net U.S. employment of these parents increased, as affiliate employment increased. This is because the fall in U.S. manufacturing employment was offset by expansion into other sectors. These trends are evident in the data reported in Tables 1 and 2 .

The fact that affiliate expansion has been accompanied by U.S. job contraction within manufacturing is an important message that should not be lost in the political rancor surrounding the topic. As U.S. parents have shifted towards services and wholesale trade, they initially expanded very little outside the United States. More recently, however, affiliate expansion in these areas has increased. If the services industry follows the trends we have identified in manufacturing, then outsourcing in services can also be expected to lead to substitution of domestic workers by lowercost foreign workers. It remains to be seen how important that expansion is for U.S. employment trends when the BEA 2004 data are released. The evidence presented in the 2004 report, which the administration was so reluctant to make public, suggests that U.S. firms in high tech sectors are indeed relocating abroad, and that their primary motivation is to cut labor costs and minimize the high start-up expenses associated with expansion at home. 


\section{How Much Do We Know About Services Outsourcing?}

W hile there is general agreement that offshore outsourcing of business services, such as back office processing, represents a new and growing type of offshore activity, very little is actually known about the extent of this "new type of trade." While countries keep careful accounts of the amount of international trade in goods that enters and leaves the country, accounting for the amount of services contracted out by companies in different foreign locations is not easy. While the
BEA keeps statistics on the activities of U.S. companies with foreign affiliates, this is different than measuring arm's-length agreements between a U.S. company and a separate entity that would provide back-office processing. The latest publicly available data provided by the BEA is for 1999; yet much of the increase in offshore outsourcing in services has probably increased within the last five years, as advances in communication have made it easier to contract for services from abroad.

The general consensus on offshore outsourcing of services is that it probably affects a small frac-

\section{Table 1}

Trends of U.S. Multinationals in Manufacturing 1977-1999

\begin{tabular}{|c|c|c|c|c|c|c|c|}
\hline Variable & 1977 & 1982 & 1989 & 1994 & 1999 & $\begin{array}{c}\text { \% Change } \\
77-99\end{array}$ & $\begin{array}{c}\text { \% Change } \\
82-99\end{array}$ \\
\hline Number of Parents & 1746 & 1154 & 1211 & 1199 & 878 & $-98.86 \%$ & $-31.44 \%$ \\
\hline Number of Countries in which Parents Have Affiliates & 21.19 & 20.61 & 20.35 & 21.54 & 19.78 & $-7.14 \%$ & $-4.17 \%$ \\
\hline Developed Countries & 12.25 & 12.54 & 13.47 & 13.41 & 11.33 & $-8.13 \%$ & $-10.70 \%$ \\
\hline Developing Countries & 8.80 & 7.98 & 6.81 & 8.09 & 8.45 & $-4.11 \%$ & $5.63 \%$ \\
\hline Affiliate Share of Jobs & $28.33 \%$ & $26.57 \%$ & $31.43 \%$ & $33.91 \%$ & $35.62 \%$ & $20.46 \%$ & $25.40 \%$ \\
\hline Developed Country Affiliate Share of Jobs & $20.09 \%$ & $18.43 \%$ & $21.59 \%$ & $22.78 \%$ & $20.98 \%$ & $4.24 \%$ & $12.14 \%$ \\
\hline Developing Country Affiliate Share of Jobs & $8.22 \%$ & $8.11 \%$ & $9.84 \%$ & $11.08 \%$ & $14.64 \%$ & $43.88 \%$ & $44.62 \%$ \\
\hline Affiliate Share of Compensation & $18.97 \%$ & $17.56 \%$ & $22.96 \%$ & $25.61 \%$ & $24.17 \%$ & $21.52 \%$ & $27.36 \%$ \\
\hline Developed Country Affiliate Share of Compensation & $16.35 \%$ & $14.44 \%$ & $20.15 \%$ & $21.95 \%$ & $19.27 \%$ & $15.16 \%$ & $25.09 \%$ \\
\hline Developing Country Affiliate Share of Compensation & $2.59 \%$ & $3.09 \%$ & $2.80 \%$ & $3.63 \%$ & $4.89 \%$ & $47.05 \%$ & $36.80 \%$ \\
\hline Affiliate Share of Total Investment & $25.99 \%$ & $23.29 \%$ & $25.14 \%$ & $29.08 \%$ & $29.10 \%$ & $10.66 \%$ & $19.96 \%$ \\
\hline Developed Country Affiliate Share of Investment & $20.12 \%$ & $17.29 \%$ & $20.95 \%$ & $23.72 \%$ & $20.88 \%$ & $3.63 \%$ & $17.21 \%$ \\
\hline Developing Country Affiliate Share of Investment & $5.67 \%$ & $5.80 \%$ & $4.17 \%$ & $5.33 \%$ & $8.22 \%$ & $30.97 \%$ & $29.36 \%$ \\
\hline \multicolumn{8}{|l|}{ Parents } \\
\hline Total Employment & 11017 & 9771 & 9137 & 6893 & 7181 & $-53.42 \%$ & $-36.07 \%$ \\
\hline Real Total Compensation (per worker) & 31.34 & 31.82 & 33.25 & 36.67 & 37.87 & $17.24 \%$ & $15.97 \%$ \\
\hline Labor's Share & 0.96 & 0.91 & 0.84 & 0.86 & 0.79 & $-21.54 \%$ & $-15.03 \%$ \\
\hline \multicolumn{8}{|l|}{ Developed Country Affiliates: All } \\
\hline Total Employment & 3089 & 2753 & 2876 & 2376 & 2531 & $-22.05 \%$ & $-8.78 \%$ \\
\hline Real Total Compensation (per worker) & 21 & 21 & 27 & 31 & 27 & $20.32 \%$ & $20.05 \%$ \\
\hline Labor's Share & 0.61 & 0.59 & 0.57 & 0.57 & 0.30 & $-101.76 \%$ & $-95.15 \%$ \\
\hline \multicolumn{8}{|l|}{ Developing Country Affiliates: All } \\
\hline Total Employment & 1263 & 1079 & 1311 & 1156 & 1766 & $28.48 \%$ & $38.91 \%$ \\
\hline Real Total Compensation (per worker) & 11 & 10 & 9 & 9 & 8 & $-38.25 \%$ & $-19.93 \%$ \\
\hline Labor's Share & 1.09 & 1.18 & 0.61 & 0.60 & 0.67 & $-62.86 \%$ & $-76.96 \%$ \\
\hline
\end{tabular}

Source: Bureau of Economic Analysis. Note: Data is for manufacturing parents and their manufacturing affiliates with non-missing observations for labor's share of income, positive employment, and non-zero production employment. Multiple affiliates in one country are treated as one affiliate. Weighted by employment shares, where applicable. Real wages, real benefits, and real total compensation are in '000 of 82-84 U.S. dollars; real net income and real total assets are in '000,000 of 82-84 U.S. dollars. Employment figures are in '000. Return on capital is net income over total assets. Variability in countries of affiliates is defined as the total number of countries in which the parent added or dropped an affiliate between the previous benchmark survey and the present one. 
tion of the U.S. labor force, but that it is growing quickly. Two reports by Forrester Research estimate that the number of U.S. services jobs outsourced will reach 3.4 million by 2015. Yet as pointed out by Bhagwati, Panagariya, and Srinivasan (2004) these numbers do not explain whether the U.S. economy will have 3.4 million fewer jobs in 2015, or whether these many workers will have shifted to different jobs as a result of outsourcing. Most economists believe that the aggregate number of jobs in an economy is determined by macroeconomic factors, not by the pressures of international competition. In addition, millions of jobs are created and destroyed within the U.S. economy each year. In 2003, for example, 30 million new jobs were created and a similar number were destroyed. Estimates on the number of jobs lost to offshore outsourcing suggest the number is very small. For example, the U.S. Bureau of Labor Statistics reported 183,000 mass layoffs in the first quarter of 2004, out of which only 4 percent were due to jobs moving overseas and only 1 percent due to service jobs moving overseas (Trefler 2005).

Nevertheless, a number of observers remain concerned because the rate of growth of offshore outsourcing for services is very high, which makes it difficult to predict anything with certainty

\section{Table 2}

\section{Trends of U.S. Multinationals in Services 1977- 1999}

\begin{tabular}{|c|c|c|c|c|c|c|c|}
\hline Variable & 1977 & 1982 & 1989 & 1994 & 1999 & $\begin{array}{c}\text { \% Change } \\
77-99\end{array}$ & $\begin{array}{c}\text { \% Change } \\
82-99 \\
\end{array}$ \\
\hline Number of Parents & 58 & 76 & 112 & 133 & 242 & $317.24 \%$ & $218.42 \%$ \\
\hline Number of Countries in which Parents Have Affiliates & 6.74 & 4.12 & 4.92 & 6.97 & 11.62 & $72.31 \%$ & $182.10 \%$ \\
\hline Developed Countries & 5.19 & 3.10 & 4.27 & 5.64 & 7.61 & $46.66 \%$ & $145.72 \%$ \\
\hline Developing Countries & 1.56 & 1.02 & 0.65 & 1.33 & 3.94 & $153.04 \%$ & $284.93 \%$ \\
\hline Affiliate Share of Jobs & $15.43 \%$ & $9.21 \%$ & $16.93 \%$ & $19.13 \%$ & $25.09 \%$ & $62.59 \%$ & $172.39 \%$ \\
\hline Developed Country Affiliate Share of Jobs & $11.67 \%$ & $7.09 \%$ & $15.36 \%$ & $16.22 \%$ & $19.41 \%$ & $66.30 \%$ & $173.65 \%$ \\
\hline Developing Country Affiliate Share of Jobs & $3.76 \%$ & $2.12 \%$ & $1.57 \%$ & $2.91 \%$ & $5.67 \%$ & $50.86 \%$ & $167.86 \%$ \\
\hline Affiliate Share of Compensation & $13.41 \%$ & $7.25 \%$ & $14.99 \%$ & $17.30 \%$ & $21.75 \%$ & $62.20 \%$ & $200.04 \%$ \\
\hline Developed Country Affiliate Share of Compensation & $11.20 \%$ & $6.06 \%$ & $14.45 \%$ & $16.38 \%$ & $19.29 \%$ & $72.23 \%$ & $218.23 \%$ \\
\hline Developing Country Affiliate Share of Compensation & $2.21 \%$ & $1.19 \%$ & $0.54 \%$ & $0.92 \%$ & $2.46 \%$ & $11.26 \%$ & $107.00 \%$ \\
\hline Affiliate Share of Total Investment & $13.97 \%$ & $6.76 \%$ & $17.65 \%$ & $21.60 \%$ & $23.17 \%$ & $65.93 \%$ & $242.99 \%$ \\
\hline Developed Country Affiliate Share of Investment & $11.88 \%$ & $5.79 \%$ & $17.06 \%$ & $20.15 \%$ & $19.47 \%$ & $63.86 \%$ & $236.02 \%$ \\
\hline Developing Country Affiliate Share of Investment & $2.09 \%$ & $0.96 \%$ & $0.59 \%$ & $1.45 \%$ & $3.70 \%$ & $77.35 \%$ & $284.04 \%$ \\
\hline \multicolumn{8}{|l|}{ Parents } \\
\hline Total Employment & 532 & 867 & 1377 & 1658 & 4795 & $801.93 \%$ & $453.30 \%$ \\
\hline Real Wages (per worker) & 16.79 & 15.94 & 17.71 & 17.03 & 20.78 & $23.74 \%$ & $30.36 \%$ \\
\hline Labor's Share & $91.46 \%$ & $88.00 \%$ & $85.70 \%$ & $90.68 \%$ & $81.24 \%$ & $-11.17 \%$ & $-7.68 \%$ \\
\hline \multicolumn{8}{|l|}{ Developed Country Affiliates: All } \\
\hline Total Employment & 73 & 68 & 255 & 333 & 1243 & $1593.31 \%$ & $1734.97 \%$ \\
\hline Real Wages (per worker) & 13.28 & 15.05 & 13.88 & 14.45 & 13.86 & $4.37 \%$ & $-7.91 \%$ \\
\hline Labor's Share & $75.93 \%$ & $45.66 \%$ & $82.20 \%$ & $72.93 \%$ & $75.48 \%$ & $-0.60 \%$ & $65.30 \%$ \\
\hline \multicolumn{8}{|l|}{ Developing Country Affiliates: All } \\
\hline Total Employment & 24 & 20 & 26 & 60 & 363 & $1436.03 \%$ & $1696.20 \%$ \\
\hline Real Wages (per worker) & 7.43 & 9.03 & 5.38 & 4.69 & 4.45 & $-40.11 \%$ & $-50.72 \%$ \\
\hline Labor's Share & $88.58 \%$ & $94.40 \%$ & $84.72 \%$ & $90.09 \%$ & $84.79 \%$ & $-4.28 \%$ & $-10.17 \%$ \\
\hline
\end{tabular}

Source: Bureau of Economic Analysis. Note: Data is for parents and affiliates with non-missing observations for labor's share of income and positive employment. Multiple affiliates in one country are treated as one affiliate. Excluding firms in the top and bottom $1 \%$ on the basis of labor shares and return to capital. Weighted by employment shares, where applicable. Real wages are in '000 of 82-84 U.S. dollars. Employment figures are in ' 000 . 
about the state of the U.S. economy in the year 2015. While aggregate employment is determined by factors other than international trade or offshoring, it is evident that wages will adjust as some types of jobs are shifted abroad and replaced by other types of employment. The extent to which "good" jobs are created or lost, however, will depend primarily on investments in physical and human capital. If the U.S. invests heavily in educating its future generations, then these workers will be able to exploit the benefits of globalization, raise productivity, and consequently increase wages by outsourcing lower-end tasks.

\section{Our Own Research}

0 ur work differs from previous research in important ways. First, we account for the fact that hiring an additional worker in a highwage country-where U.S. firms are likely to have sales and other operations-is likely to have a different impact on U.S. employment than hiring a worker in a low-wage country, where U.S. firms have much smaller markets and are more likely to be executing business generated elsewhere. ${ }^{8}$ Second, we separately identify the impact on U.S. employment of increasing investment by U.S. companies at home, in low-wage and in high-wage affiliate locations. Third, we allow for the impact of technological change and import competition and address the possibility that methodological differences might be driving differences in results by including additional relevant variables in a multivariate regression. ${ }^{9}$

Our research suggests that measuring the impact of outward investment on U.S. employment at home is a particularly important omission. While the negative impact of U.S. investment abroad on home employment has been overlooked by academics, it is a topic of great interest in the U.S. Congress. On October 22, 2004, the Con-

${ }^{8}$ Although Brainard and Riker (2001) do this, they do not account for the impact of all of the firms' choice variables on U.S. parent employment.

${ }^{9}$ We also use an instrumental variables approach to control for potential endogeneity. Instrumental variables estimations corrects for the fact that when both the dependent variable (domestic employment) and the independent variables (foreign employment) in a regression are determined concurrently by the firm, the strength of the relationship will be mismeasured. gress of the United States passed the American Jobs Creation Act of 2004. According to Section 422 of this act, U.S. parent companies that repatriate earnings from their foreign affiliates to invest in the U.S. are subject to a reduced tax rate on the repatriated earnings. ${ }^{10,11}$ Section 965 of this act identifies types of U.S. investments for which repatriated funds may be used and includes: hiring and training workers, infrastructure and capital investments, research and development, financial stabilization for the purposes of U.S. job retention or creation, certain acquisitions of business entities with U.S. assets, advertising and marketing and acquisition of rights to intangible property such as patent rights. ${ }^{12}$ Our research suggests that encouraging domestic investment is indeed associated with domestic job creation, while investment in affiliates reduces domestic manufacturing employment.

We analyze the firm-level surveys on U.S. direct investment abroad, collected each year by the Bureau of Economic Analysis (BEA) of the U.S. Department of Commerce. The BEA collects confidential data on the activities of U.S.-based multinationals, defined as the combination of a single U.S. company that has made the direct investment, called the parent, and at least one foreign business enterprise, called the foreign affiliate. According to Mankiw and Swagel, these are the only reliable data available to analyze the effects of offshore activities on the U.S. economy. We use the data collected on majority-owned, nonbank foreign affiliates and non-bank U.S. parents for the benchmark years between 1977 and 1999. The benchmark years are 1977, 1982, 1989, 1994, and 1999 and include more comprehensive information than the annual surveys. To our knowledge, very little work has been done with the

\footnotetext{
${ }^{10}$ We thank Ralph Kozlow for pointing this out.

11 The effective reduction in tax rates is substantial. The U.S. company can deduct $85 \%$ of the repatriated dividends. Thus, if the company is subject to a $35 \%$ corporate tax rate on the $15 \%$ of dividends not covered, the company's effective tax rate on the total repatriated dividend is $5.25 \%$.

12 These funds may not be used for: executive compensation, intercompany transactions, dividends and other shareholder distributions, stock redemptions, portfolio investments, debt instruments, and tax payments.
} 
firm-level data using the entire length of the time series from 1977 through 1999. ${ }^{13}$

While the number of U.S. parent companies included in the BEA sample may appear small, sales by these enterprises over the period 1982 to 1999 (see Table 1) accounted for over 60 percent of total manufacturing sales in the United States. ${ }^{14}$ These enterprises also accounted for 71 percent of all exports of goods, and nearly 60 percent of employment in manufacturing. These multinationals also account for most of U.S. research and development expenditures: over the period 1982 to 1999 , the U.S. parents included in the BEA sample account for 82 percent of total U.S. research and development expenditures.

Table 1 shows that between 1977 and 1999 multinational manufacturing firms shed more than 3 million jobs in the United States. ${ }^{15}$ Table 1 also documents that labor's share of income (defined as parent compensation divided by the sum of parent compensation and parent net income) in the U.S. has fallen from 96 to 79 percent. While the fall in labor's share is consistent with recent reductions in labor's share of income in U.S. GDP, the decline is also consistent with the fact that manufacturing in the United States has become increasingly capital-intensive. The loss of jobs in the U.S. has been mirrored by job reductions for affiliates in developed countries, with the greatest declines in the United Kingdom, Canada, France, and Japan. These job losses have

\footnotetext{
${ }^{13}$ For details on data construction, see our NBER working paper, Harrison and McMillan (2006).

${ }^{14}$ See the December 1996 issue of The Survey of Current Business, "Operations of US Multinational Companies: Preliminary Results from the 1994 Benchmark Survey," by Mataloni and Fahim-Nader, as well as the authors' own calculations.

${ }^{15}$ It is important to note, however, that some of these changes in employment might simply reflect acquisitions and spin-offs. However, at least in the aggregate, since most sales of U.S. multinationals are to other U.S. multinationals, and the firms would still remain in our database even if they were acquired, information about spinoffs is only available for 1989 to the present.

The variables we use are reported to the BEA on the basis of the fiscal year. General trends in employment weighted averages are reported in Table 1 for manufacturing and in Table 2 for services. The numbers in Table 2 include all firms classified in services under the SIC classification prior to 1997 and under the NAICS system post-1997. Because the NAICS system classifies some industries as services that were not previously classified as services, the employment numbers are slightly exaggerated. However, when we restrict our analysis of services to only those sub-categories that can be exactly matched across years, we get nearly identical trends.
}

been only partially offset by an increase in the number of jobs in developing countries, where employment expansion was greatest in two countries: Mexico and China. In developing country affiliates, the number of jobs increased by half a million between 1977 and 1999 and by three quarters of a million between 1982 and 1999. In developing countries, labor's share also fell. Unlike in the developed countries, real wages paid by U.S.based multinationals to employees in their developing country affiliates have actually fallen. The evidence for the U.S. parents is in line with the aggregate trends in the U.S. manufacturing sector. ${ }^{16}$ To summarize, in U.S.-based manufacturing multinational firms, jobs have declined within the U.S. and in the operations in developed countries. While wages have increased slightly in high income affiliates, labor's share of income has fallen in both the United States and in high income affiliates, reflecting in part increasing capital intensity. In developing countries, employment is rising, but wages have declined, presumably reflecting the constant search for cheaper labor costs.

The proportion of total global employment of U.S. manufacturing-based multinationals that are based outside the U.S. increased from 28 percent in 1977 to 35 percent in 1999. The increase was almost entirely driven by a doubling of affiliate employment shares in developing countries, from 8 to 15 percent. Affiliate employment in developed countries, as a share of total worldwide employment, remained roughly constant over the entire period at around 20 percent. The percentage of employment, all employee compensation, and investment accounted for foreign affiliates increased by 20, 22 and 11 percent, respectively, over this period. This increase in overseas activity has been largely reserved for developing countries where the respective increases are 44, 47 and 31 percent.

Among these multinational firms, the contraction in domestic jobs in the manufacturing sector

\footnotetext{
${ }^{16}$ According to the NBER Manufacturing Productivity Database, labor's share in value-added declined from .53 to .31 - roughly $50 \%$ - over the period 1958 to 1996 . Over the period of time for which the two datasets overlap, employment and labor's share in income both move in the same direction - down.
} 
has been more than offset by job creation in the services sector. ${ }^{17}$ Table 2 presents results for service sector operations and shows that between 1977 and 1999, total employment by U.S. companies increased by more than 4 million or 802 percent. Jobs expanded at home and abroad. Employment increased from 73,000 in 1977 to 1.2 million in 1999 in developed countries and from 24,000 in 1977 to 363,000 in 1999 in developing countries. While affiliate activity in services is still less than that for manufacturing, it has nonetheless been growing more rapidly. Foreign affiliate shares in U.S. firms' world-wide employment, employee compensation, and investment has risen by 63, 62, and 66 percent, respectively. The expansion of U.S. multinationals into developing countries has been accompanied by a reduction in labor's share at the parent level of 11 percent. Unlike in manufacturing, labor's share overseas has remained relatively constant.

It is important to keep in mind that throughout the period 1977-1999, real compensation per worker in the service sector amounts to little more than half of real compensation per worker in the manufacturing sector. This may be partly a reflection of a change in the mix of workers in the U.S. manufacturing sector-if lower-wage, unskilled jobs in the U.S. have gone abroad, then the average wage in the U.S. manufacturing sector may rise. However, the fact that this differential existed even in 1977 before the big contraction in U.S. manufacturing suggests that this is not the only reason for the difference. What Tables 1 and 2 do show is that employment in manufacturing has declined while employment in services has increased, and that average compensation in services was well below compensation in manufacturing even at the start of the sample period.

\section{Broad Trends}

W e now turn to a discussion of broad trends in the pattern of manufacturing employment changes in U.S. parents and their affiliates. We restrict our analysis to the period 1982 to 1999

\footnotetext{
${ }^{17}$ The classification of a firm into manufacturing or services is based on NAICS codes, which are standard ways of classifying the output of an enterprise. Whether an enterprise is classified into one or another sector depends whether the majority of its sales are in manufacturing or services.
}

for comparability with the work by Brainard and Riker (1997, 2001) and Desai et al. (2005) who used these same data beginning in 1982. As a first test of whether U.S. parents are substituting U.S. employment with affiliate employment, we created a series of graphs to show how employment in foreign affiliates affects employment at home. In Figure 1, changes in parent (U.S.) total manufacturing employment are indicated by the horizontal axis and changes in affiliate total manufacturing employment are indicated by the vertical axis. A point in the upper right-hand quadrant indicates expansion both at home and abroad. A point in the lower left-hand side quadrant indicates contraction at home and abroad. Substitution occurs if data points are either in the upper left-hand quadrant (indicating contraction at home and expansion in affiliate employment) or in the lower right-hand quadrant (indicating expansion at home and contraction abroad).

Most U.S. critics of globalization center on supposed activity in the upper left-hand quadrant, which would indicate expansion of affiliate employment and contraction of employment in the U.S.; so-called substitution of foreign for U.S. jobs. As Figure 1 shows, most of the activity of U.S. manufacturing multinational enterprises has taken place in the upper and lower left-hand quadrants, indicating employment contraction at home. Almost half of the reported activity has taken place in the upper left hand quadrant, indicating contraction at home and affiliate expansion.

Figures 2 and 3 separate changes in employment from 1982 to 1999 based on the location of the parent's affiliates. Figure 2 reports employment changes for developed country affiliates and parents; Figure 3 reports the same trends for developing country affiliates. The trends are similar across Figures 1 and 2-employment in highincome affiliates and parent employment are complementary but that relationship is driven by the contraction in manufacturing. However, Figure 3 reveals that employment in low-income affiliates substitutes for employment in the U.S. Moreover, the downward sloping regression line appears to be driven by contraction in two key sectors: computers and electronics. 
While the stylized facts reported in Tables 1 and 2 and the figures are useful for explaining why opinions on the outsourcing of U.S. jobs are so different, these facts do not tell us enough about the underlying mechanisms at work. The fact that substitution occurs only between U.S. jobs and jobs in low-wage countries suggests that labor costs are an important factor in that process. Our goal is to estimate and compare the relative impacts of alternative modes of globalization on U.S. jobs and wages, taking into account differences in aggregate demand, factor prices, and technology shocks across different locations.

\section{Results}

P revious work has used a variety of approaches to test for the impact of foreign affiliate activity on labor demand at home. To help us disentangle why previous results seem to contradict each other, we adopt a general enough framework that we can imbed all these different approaches into our estimation strategy and compare results for consistency across specifications. Our first result confirms the conclusions reached by Desai et al.: aggregating across all locations, em- ployment expansions and contractions in U.S. multinational parents and their affiliates on average move in the same direction. A 10 percent increase in foreign employment would lead to a 1.22 percent increase in U.S. parent employment. However, this correlation is driven by the overall contraction in U.S. manufacturing employment, which has been accompanied by an overall contraction in affiliate employment. We then show that these averages mask significant heterogeneity across different kinds of enterprises.

For those companies that employ workers in developing countries-roughly half the samplethe story is different. For these firms, the contraction in U.S. manufacturing employment has been accompanied by an increase in affiliate employment. This evidence suggests that employment in low-income affiliates substitutes for U.S. employment. The estimates imply that a 10 percent increase in affiliate employment in high-income countries is associated with a .4 to .5 percent increase in U.S. employment, while a 10 percent increase in affiliate employment in low-income countries is associated with a 3 to 2.1 percent fall in U.S. employment. If employment in high-

\section{Figure 1}

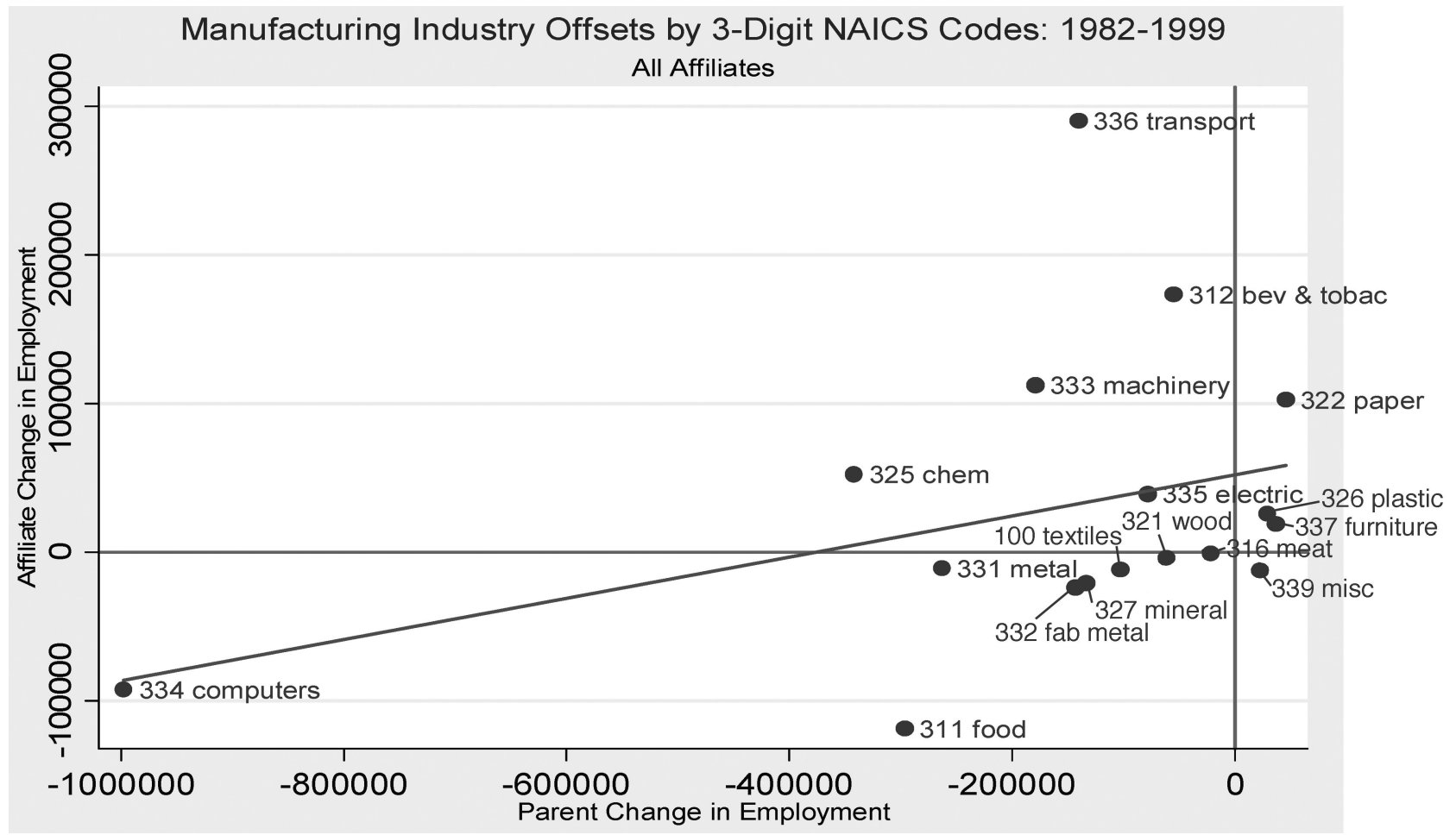


income affiliates is positively correlated with U.S. employment, then the contraction in highincome affiliate employment implies a fall in U.S. employment. Similarly, expansion in low-income affiliates is associated with a fall in U.S. employment; the documented expansion of U.S. multinational affiliates in low-income regions helps explain the downsizing of manufacturing employment in the United States. We also examine separately the impact of hiring skilled and unskilled labor abroad. We find that substitution between U.S. and foreign affiliate labor occurs primarily within unskilled worker categories in low income countries. In other words, the low wage, unskilled jobs are the ones going to lowincome countries.

Although the negative impact of affiliate employment in low-income countries on U.S. manufacturing employment is statistically significant, other factors have also played an important role in determining employment at the firm level. Our research suggests that an expansion in the U.S. capital stock increases home manufacturing em- ployment, while an expansion in the affiliate capital stock reduces home employment. The reason for this, of course, is that capital investment represents machinery and equipment, and jobs are tied to those investments. A 10 percent increase in the capital stock at home is associated with an increase in U.S. manufacturing employment of between 6.4 and 10.4 percent. Conversely, a 10 percent increase in capital stock in high- or lowincome affiliates is associated with a decline in U.S. employment of between .1 and 1.8 percent. Since the capital stock in affiliates increased by over 100 percent between 1982 and 1999, this diversion of investment towards affiliates resulted in a decline of up to 24 percent in U.S. manufacturing employment. Although our research shows that it is difficult to be sure about the precise magnitude of the effect of overseas investment by U.S. companies on their domestic employment, one result is clear: the impact is negative.

Increases in trade, both arm's length and between the U.S. parent and its affiliates, are also associated with a reduction in labor demand at

\section{Figure 2}

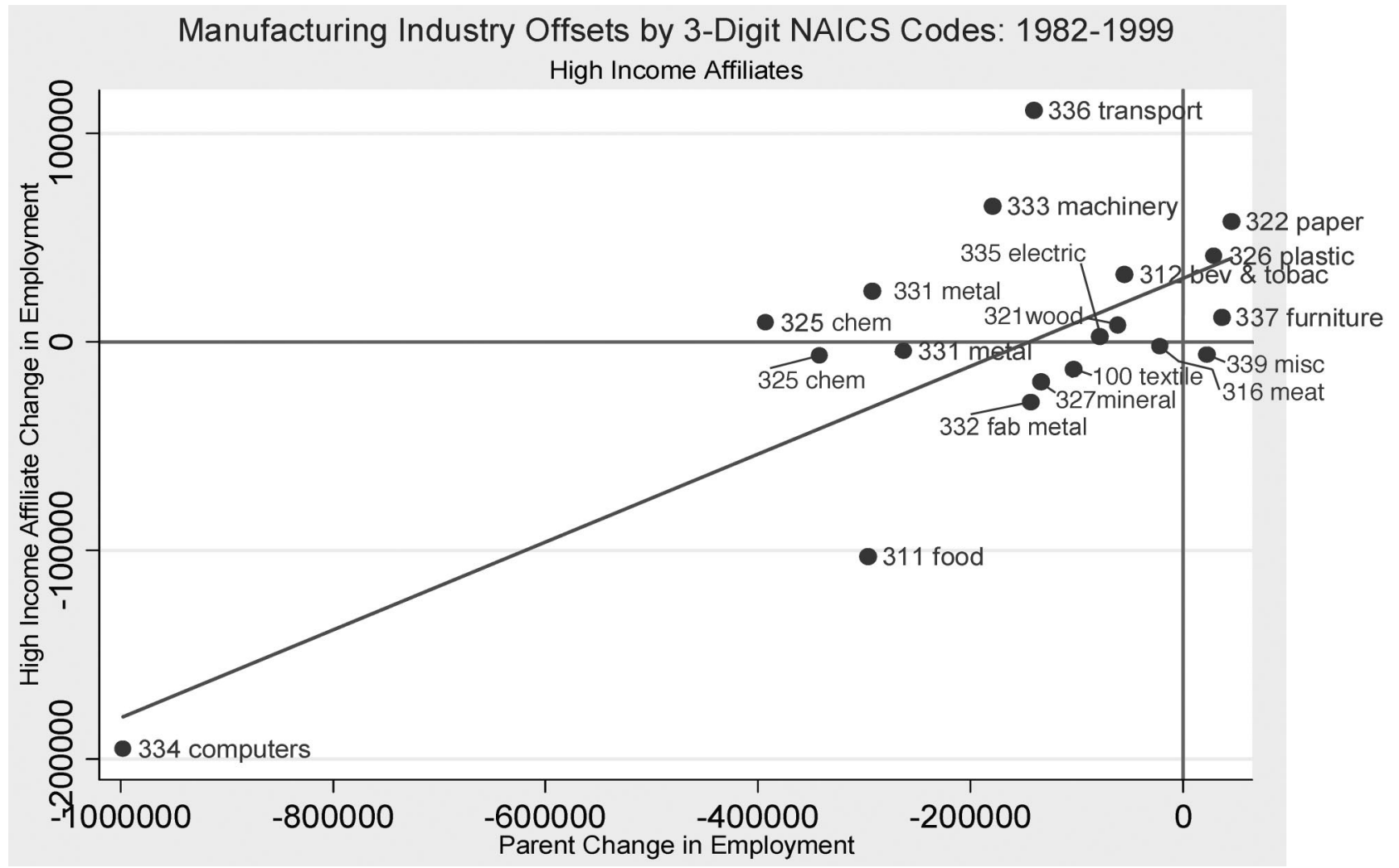


home. The over 10 percentage point increase in arm's length import competition within the U.S. facing the multinational companies in our sample was associated with a decline in U.S. manufacturing employment of 2 to 3 percent. Increases in imports from (exports to) the foreign affiliate are also associated with a fall in U.S. employment. While a decline in domestic employment associated with increasing exports from the U.S. parent to its foreign affiliate seems puzzling, the data shows a strong positive correlation between exports to foreign affiliates and exports to foreign affiliates for "further processing." These exports may be unfinished goods that will be completed by foreign workers - essentially offshoring. Foreign demand shocks are also associated with significant effects on U.S. employment, suggesting that foreign GDP growth in affiliate locations promotes employment at home.

The overall reduction in labor intensity within U.S. manufacturing is partially explained by the fact that technological changes in recent years has been "labor-saving," leading to greater productiv- ity and the need for fewer workers. We examine technological change using the share of research and development employees in the firm's labor force as a proxy variable. Our estimates suggest that a 10 percentage point increase in the parent's $R \& D$ employee share would be associated with a 5 to 9 percentage point decline in total parent employment. Although parent R\&D employment only increased by 2.1 percentage points on average between 1982 and 1999 (implying a reduction in home employment of 1 to 2 percent), the coefficient estimates suggest that technological change as a source of falling manufacturing employment could be important in the future.

Our results indicating that employment in lowincome affiliates is a substitute for U.S. employment are robust to whichever framework we choose, although the magnitudes vary. However, the large employment increases and significant wage declines in developing countries (see Table 1) only partially explain the large observed fall in employment in the United States. Other aspects of globalization have also played a significant role.

\section{Figure 3}

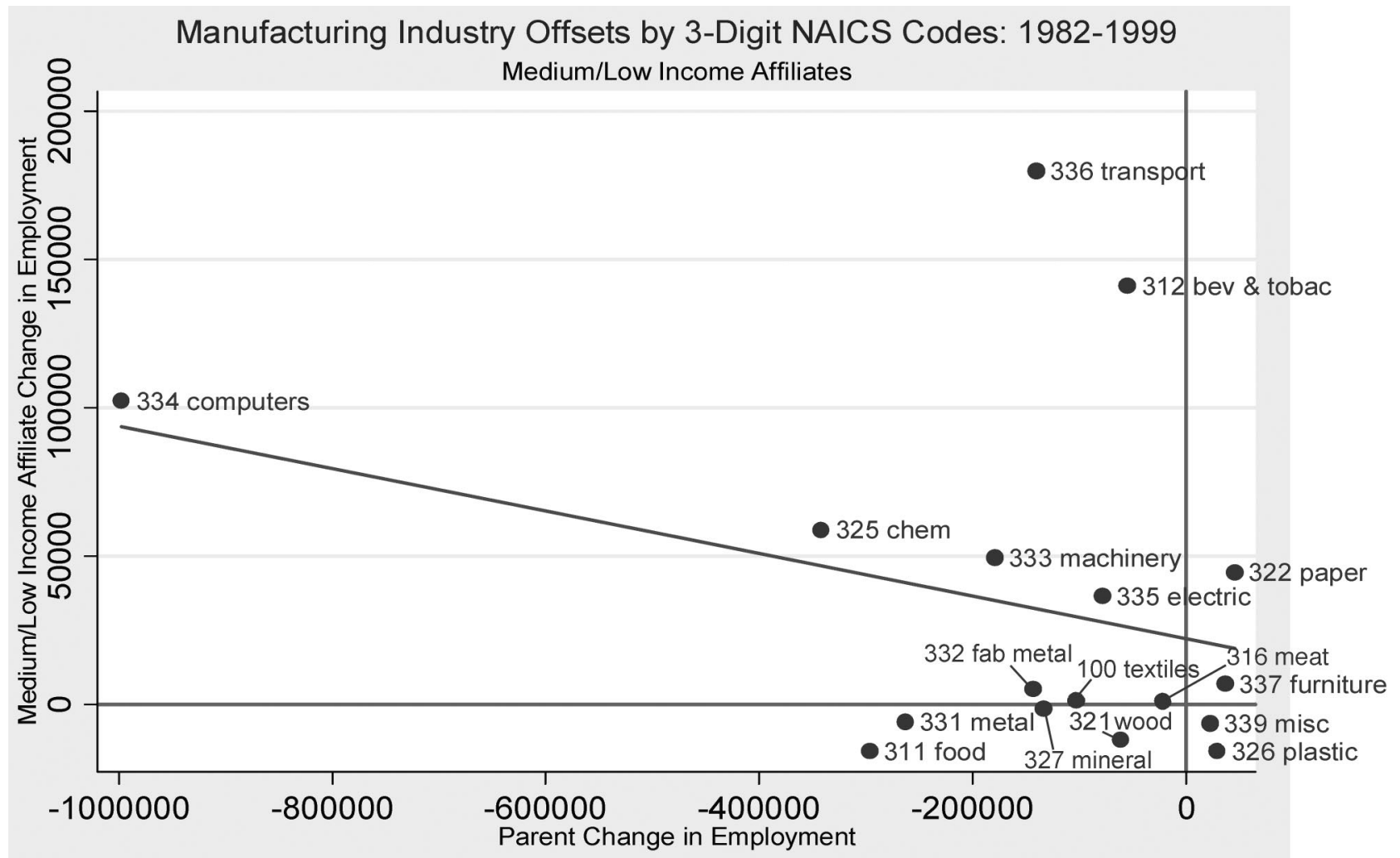


One factor that has not received any attention in previous literature is the impact of U.S. multinationals expanding their physical investments abroad. Increases in the capital stock in foreign affiliates are associated with significant declines in U.S. employment. These declines are at least as important in magnitude as the impact of expanding foreign employment. All the approaches show that both arm's length trade, as captured by U.S. import penetration, and intra-firm trade have also played an important role in reducing U.S. manufacturing employment.

We summarize the effect of all these different factors on U.S. manufacturing employment in Table 3. We combine the coefficient estimates discussed above with actual changes in employment, investment, trade, R\&D intensity, and GDP per capita changes across affiliate locations. The complete picture shows that the major determinants of contraction in U.S. manufacturing parent employment have been: 1) increased employment in low income affiliates, 2) increased physical investment abroad, and 3) goods imported from the affiliate to its U.S. parent. The employment losses associated with the expansion of U.S. investment in low-income countries are three times more important than the employment losses due to hiring more workers in those countries. The major determinants of employment expansion at home are increases in U.S. physical investment and increases in GDP per capita in high-income affiliates, who are more likely to be customers for the products and services of the U.S. companies.

Why should employment levels of operations

\section{Table 3}

\section{Calculating the Impact of Different Aspects of Globalization on U.S. Employment Outcomes}

\begin{tabular}{|c|c|c|c|c|c|}
\hline $\begin{array}{l}\text { Factors Affecting U.S. Labor } \\
\text { Demand }\end{array}$ & $\begin{array}{c}\text { Impact of a } 10 \\
\text { percent Increase in } \\
\text { Factor on } \\
\text { Percentage Change } \\
\text { in U.S. Employment } \\
\text { (OLS Estimates) } \\
\text { (1) }\end{array}$ & $\begin{array}{l}\text { Impact of a } 10 \\
\text { percent Increase } \\
\text { in Factor on } \\
\text { Percentage Change } \\
\text { in U.S. Employment } \\
\text { (Instrumental } \\
\text { Variable Estimates) } \\
\text { (2) }\end{array}$ & $\begin{array}{c}\text { Actual Increase } \\
\text { in Factor in BEA } \\
\text { Sample } \\
\text { (3) }\end{array}$ & $\begin{array}{l}\text { Minimum } \\
\text { Percentage Change } \\
\text { in Labor Demand } \\
\text { (Equals Column (1) } \\
\text { x Column (3)) } \\
\text { (4) }\end{array}$ & $\begin{array}{l}\text { Maximum } \\
\text { Percentage Change } \\
\text { in Labor Demand } \\
\text { (Equals Column (2) } \\
\text { x Column (3)) } \\
\text { (5) }\end{array}$ \\
\hline $\begin{array}{l}\text { Log Employment } \\
\text { High-Income Affiliates }\end{array}$ & $0.44 \%$ & $0.49 \%$ & $-8.8 \%$ & $-.039 \%$ & $-0.043 \%$ \\
\hline $\begin{array}{l}\text { Log Employment } \\
\text { Low-Income Affiliates }\end{array}$ & $-0.31 \%$ & $-2.11 \%$ & $38.9 \%$ & $-1.21 \%$ & $-8.21 \%$ \\
\hline Log Parent Capital Stock & $6.43 \%$ & $10.37 \%$ & $34.8 \%$ & $22.38 \%$ & $36.09 \%$ \\
\hline $\begin{array}{l}\text { Log Capital Stock } \\
\text { High-Income Affiliates }\end{array}$ & $-0.14 \%$ & $-0.22 \%$ & $123.9 \%$ & $-1.73 \%$ & $-2.73 \%$ \\
\hline $\begin{array}{l}\text { Log Capital Stock } \\
\text { Low-Income Affiliates }\end{array}$ & $-0.20 \%$ & $-1.81 \%$ & $130.5 \%$ & $-2.61 \%$ & $-23.62 \%$ \\
\hline U.S. R\&D Employment Share & $-5.30 \%$ & $-8.52 \%$ & $2.1 \%$ & $-1.11 \%$ & $-1.79 \%$ \\
\hline U.S. Import Penetration & $-1.90 \%$ & $-3.43 \%$ & $11.0 \%$ & $-2.09 \%$ & $-3.77 \%$ \\
\hline $\begin{array}{l}\text { High-Income Affiliates } \\
\text { Log GDP per capita }\end{array}$ & $0.20 \%$ & $0.21 \%$ & $151.0 \%$ & $3.02 \%$ & $3.17 \%$ \\
\hline $\begin{array}{l}\text { Low-Income Affiliates } \\
\text { Log GDP Per Capita }\end{array}$ & $0.10 \%$ & $-0.01 \%$ & 18.00 & $0.18 \%$ & $-.02 \%$ \\
\hline $\begin{array}{l}\text { Exports to Foreign Affiliates } \\
\text { (Share in Sales) }\end{array}$ & $-4.10 \%$ & $-23.99 \%$ & $1.2 \%$ & $-0.49 \%$ & $-2.89 \%$ \\
\hline $\begin{array}{l}\text { Imports from Foreign Affiliates } \\
\text { (Share in Sales) }\end{array}$ & $-1.00 \%$ & $-50.93 \%$ & $2.2 \%$ & $-0.22 \%$ & $-11.20 \%$ \\
\hline
\end{tabular}

Note: Numbers in column (1) taken from Table 5; column (4) from Harrison and McMillan (2006); column (3), first two rows taken from Table 1 in this paper; column (3) remaining rows taken from Table 3 of Harrison and McMillan (2006); column (4) is calculated as the product of columns (1) and (3); column (5) is calculated as the product of columns (2) and (3). 
in high- and low-income countries have different effects on the level of employment back in the United States? Multinationals setting up affiliates in low-income countries are attracted by low labor costs, and consequently are replacing U.S. with foreign labor to manufacture their goods. Multinationals locating in high-income countries are more attracted by potential market opportunities, and consequently expansion abroad is complementary with employment at home. These different motivations for offshore activity lead to different effects on U.S. employment. Hiring by affiliates hurts U.S. employment when those affiliates are in low-income countries but helps U.S. employment when those affiliates are in highincome countries. Since all the recent expansion of offshore outsourcing in manufacturing has been in low-income countries, we can expect further substitution of U.S. manufacturing jobs in the future.

These differences in impact on U.S. employment should also provide insight into how future offshoring of services will affect the U.S. labor force. Our research also highlights how misleading a pure emphasis on the flow of jobs abroad can be for understanding U.S. employment levels, as many other factors affect domestic employment decisions. In particular, Table 3 shows that physical investment in any affiliate location hurts U.S. employment, providing support for recent congressional efforts to promote domestic investment.

\section{Concluding Comments}

W e began this essay by surveying the existing studies on the phenomenon of offshoring, which we define as expansion by U.S.-based multinationals in foreign locations. Focusing on manufacturing, we identify a reluctance on the part of some economists to admit that offshoring could be accompanied by the displacement of directly affected workers. In fact, a number of prominent economists have argued that U.S. multinationals create manufacturing jobs at home when they locate operations abroad. We take issue with this claim, citing both previous studies on the subject as well as our own research.

Over the period 1977 to 1999 multinational manufacturing firms shed more than 3 million jobs in the United States. Over this same period, the number of workers hired by affiliates in developing countries increased while wages paid to these workers declined. These facts are consistent with the notion that U.S. parents are exporting low-wage jobs to low-income countries. However, the expansion in manufacturing employment in developing countries amounts to only one quarter of the jobs lost in the U.S. Other factors, such as technological change and international trade, are also important determinants of U.S. manufacturing employment.

Most research suggests that employment in low-income affiliates substitutes for U.S. employment. But the large employment increases in developing countries and significant wage declines only partially explain the observed fall in manufacturing employment in the United States. Given that the employment costs, although real, have been small, the net impact on U.S. wages is uncertain. While offshoring is likely to put downward pressure on wages by opening up alternative sources of labor supply, the productivity gains from offshore outsourcing could offset these effects (see Grossman \& Rossi-Hansberg 2006). In our ongoing research, we are exploring the impact of offshoring on the wages of U.S. workers.

Our evidence indicates one important aspect in which offshoring differs from international trade: expansion of affiliate activity is associated with a shift in U.S. investment abroad. Our research shows that increases in the capital stock in foreign affiliates are associated with significant declines in U.S. employment. Other factors have also contributed to the falling importance of manufacturing jobs in the U.S. labor force, and the concurrent rise of service employment. These factors include international trade, as captured by U.S. import penetration, intra-firm trade, and technological change.

From a policy standpoint, to impede foreign investment in low-income countries would be misguided. Allowing foreign investment to flow to low-wage locations helps U.S. companies to survive and helps those economies to grow. While policies to encourage domestic investment and education are likely to yield long-run benefits, penalizing firms that invest abroad will reduce 
their ability to compete in the world economy. Yet to deny that there are some short-term costs to some sectors of the U.S. economy is also wrong. An appropriate response is not to deny that such losses occur, but to devise programs to assist the workers who are hurt by these developments. This is exactly the message that Federal Reserve Chairman Ben Bernanke conveyed in his recent speech in Jackson Hole, Wyoming:

"...Changes in the patterns of production are likely to
threaten the livelihoods of some workers and the profits of
some firms, even when these changes lead to greater produc-
tivity and output overall. The natural reaction of those so
affected is to resist change, for example, by seeking the
passage of protectionist measures. The challenge for policy-
makers is to ensure that the benefits of global economic
integration are sufficiently widely shared-for example, by
helping displaced workers get the necessary training to take
advantage of new opportunities-that a consensus for wel-
fare-enhancing change can be obtained..."18

To deny that some workers are displaced due to offshore outsourcing is not just incorrect but is bad politics, since those workers will prevent further liberalization from taking place. Even the chairman of the Fed says so.

\section{References}

Amiti, M. \& Wei, S. 2005. International Service Outsourcing, Productivity and Employment: Evidence from the U.S. IMF Working Paper WP/05/xx, September.

Bhagwati, J., Panagariya, A., \& Srinivasan, T. N. 2004. The Muddles over Outsourcing, Journal of Economic Perspectives, 18(4): 93-114.

Brainard, L. \& Riker, D. 1997a. U.S. Multinationals and Competition from Low Wage Countries. NBER Working Paper 5959, March.

Brainard, L. \& Riker, D. 2001. Are U.S. Multinationals Exporting U.S. Jobs? In Greenaway, D. \& Nelson. D.R. (Eds.), Globalization and labour markets, Vol. 2, pp. 410 26, Cheltenham, UK and Northhampton, MA: Elgar.

Bernard, A., Jensen, J. B., \& Schott, P. 2006. Survival of the Best Fit: Exposure to Low-Wage Countries and the (Uneven) Growth of U.S. Manufacturing Plants. Journal of International Economics, 68:219-237.

Brainard, L. \& Riker, D. 1997b. Are U.S. Multinationals Exporting U.S. Jobs? NBER Working Paper 5958, March.

Budd, J. W. \& Slaughter, M. 2000. Are Profits Shared Across Borders? Evidence on International Rent Sharing, NBER Working Paper Number 8014, November.

\footnotetext{
${ }^{18}$ See http://www.federalreserve.gov/boarddocs/speeches/2006/20060825/ default.htm
}

Congress of the United States. American Jobs Creation Act of 2004. Public law 108-357. October 22, 2004.

Currie, J. \& Harrison, A. 1997. Sharing the Costs: the impact of trade reform on capital and labor in Morocco. Journal of Labor Economics, 15(3).

Desai, M., Foley, F. \& Hines, J. 2005. Foreign Direct Investment and Domestic Economic Activity, Harvard Business School Working Paper, November.

Feenstra, R. C. \& Hanson, G. 1996. Globalization, Outsourcing, and Wage Inequality, AER Papers and Proceedings, 297-322.

Feenstra, R. C. \& Hanson, G. 2003, Global Production Sharing and Rising Inequality: A Survey of Trade and Wages, Forthcoming, Handbook of International Economics.

Grossman, G. \& Rossi-Hansberg, E. 2006, Trading Tasks: a Simple Theory of Offshoring, Working Paper, Princeton University.

Hanson, G., \& Harrison, A. 1999. Who Gains from Trade Reform? Some Remaining Puzzles. Journal of Development Economics, 59: 125-154.

Hanson, G., Mataloni, R. \& Slaughter, M. 2003. Expansion Abroad and the Domestic Operations of U.S. Multinational Firms. Working Paper.

Harrison, A. 2003. Has Globalization Eroded Labor's Share? Evidence from Cross-country Data. Manuscript in progress.

Harrison, A. \& McMillan, M. 2006. Outsourcing Jobs? Multinationals and U.S. Employment. NBER Working Paper.

Mankiw, N. G. 2004. The Economic Report of the President, Council of Economic Advisors, Washington, DC, February.

Mankiw, N. G. \& Swagel, P. 2006. The Politics and Economics of Offshore Outsou. NBER Working Paper 12398, July.

Mataloni, R. J., Jr. 1999. U.S. Mulitnational Companies: Operations in 1997. Survey of Current Business, July.

Mataloni, R. J., Jr. \& Fahim-Nader, M. 1996. Operations of U.S. Multinational Companies: Preliminary Results from the 1994 Benchmark Survey. Survey of Current Business, December.

McMillan, M., Pandolfi, S. \& Salinger, L. 1999. Promoting Labor Intensive Exports in Developing Countries: Evidence from the Textile and Electronics Industries. Harvard Center for International Development, CAER Working Paper no. 22, May.

Muendler, M. \& Becker, S. O. 2006. Margins of Multinational Labor Substitution, UCSD Working Paper, April 15.

Richardson, J. D. \& Khripounova, E. B. 1998. U.S. Labor Market Power and Linkages to International Trade: Identifying Suspects and Measures. Draft for U.S. Department of Labor.

Trefler, D. 2005. Policy Responses to the New Offshoring: Think Globally, Invest Locally. Mimeo, University of Toronto, April.

U.S. Department of the Treasury, Office of Public Affairs. 2005. "FACT SHEET: Guidance on Repatriation of Foreign Earnings Under the American Jobs Creation Act," January 13. 
Copyright of Academy of Management Perspectives is the property of Academy of Management and its content may not be copied or emailed to multiple sites or posted to a listserv without the copyright holder's express written permission. However, users may print, download, or email articles for individual use. 